\title{
LXIII. Correction of an erroneous statement in the account of Mr. Bakewell's lectures, as to his originality in exhibiting a geological map of England: with remarks on the geological questions, whether the lower derbyshire strata anywhere else appear in England?; were caverns formed by subterranean currents of water?; and, how were mineral veins opened and filled?
}

Mr. John Farey Senior

To cite this article: Mr. John Farey Senior (1812) LXIII. Correction of an erroneous statement in the account of Mr. Bakewell's lectures, as to his originality in exhibiting a geological map of England: with remarks on the geological questions, whether the lower derbyshire strata anywhere else appear in England?; were caverns formed by subterranean currents of water?; and, how were mineral veins opened and filled? , Philosophical Magazine Series 1, 39:170, 425-428, DOI: $10.1080 / 14786441208638158$

To link to this article: http://dx.doi.org/10.1080/14786441208638158 
LXIII. Correction of an erroneous Statement in the Account of Mr. BaKFWFLL's Lectures, as to his Originality in exhibiting a Genlogical Map of England: with Remarks on the Geological Questions, Whether the low'er Derbyshire Strata anywhere else appear in England? ; Were Caverns formed by subterranean Currents of Water?; and, How were Mineral Veins opened and filled?. By Mr. ЈонN FAREX Senior.

\section{To Mr. Tilloch.}

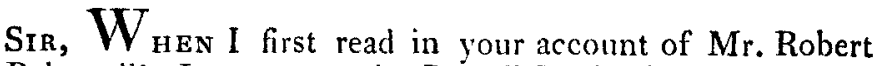
Bakewell's Lectures, at the Russell Institution, p. 234, of your March Magazine, that Mr. B. exhibited to his anditors, "a Geological Map of England, drawn for the purpose" of his Lectures, and said, "that, so far as he knew, this w'as the first atlempt to represent in a Map the geological outlines of England," I supposed this statement, of a claim to originality in mineral Maps of England, to be made, by an error or misconception of your Reporter, and which from its manifest injustice to others, would receive a speedy correction from Mr. Bakewcll, or some of those who atiended his Lectures: after waiting, however, the conclusion of his three courses, without seeng anything further on the subject, I am induced to request your permission to point out, that it is incredible that Mr. B. should have been uninformed, that Mr. IVilliam Smith of Buckingham-street, had nearly completed such a Map years ago, as very often has been mentioned in your Magazime*, in Dr. Rees's Cyclopæedia, \&c.; not to mention a work, to which $\mathrm{Mr}$. B. himself refers (at p. 236), my Derbyshire Report, vol.i. p. 108; nor is it more likely, that Mr. B. was uninformed, that a primary object of the Gerlogical Society of London, as expressed in their printed "Geological Inquiries," was to prepare "Mineral Maps of districts," or that he was altogether ignorant of the progress, that G. B. Greenough, Esq. their very able and indefatigable president had made, in a Map of England and Wales, and auother of Scotland, which have been very liberally shown (as his important collection correspondiug to them has) to great numbers, besides the members of the Society assembled at their meetings; which last Maps, from combining, all that had been learnt from Mr. Smith, either directly or through me, or others who have examined his Maps and collection, with

* Particularly in volume rxxv. p. 114.

Vol.39. No. 170. June 1812。 E e

the 
the extensive and systematic observations of Mr. G. himself, and the more local observations of others on the British strata, and with most of what has been from time to time published on the British strata, and on the unstratified districts of Cornwall, the central and northern parts of Wales, the Malvern Hills, Charnwood Forest, parts of Westmoreland, Cumberland, and Northumberland, \&c. and of great part of Scotland (with which last districts Mr. Smith had not inuch concerned himself), are, doubtless, mach more exiensive and correct, than anything that Mr. B. would be able to produce, or at least, to which he could justly lay claim, without acknowltdgement of the sources whence be derived part at least of his materials. I was, therefore, and still am desirous, sir, of thinking, that Mr. B. only intended to say, that this was the first time that a Geolugical Map of England had been exhibited in a course of pulic Lectures expressly on the subject; which yet, if it be literally true, will scarcely render this claim of $\mathrm{Mr}$. B. a fair one, as it is stated, when it is considered, that Mr. Greenough's Maps have, often I believe, been exhibited to geological assemblies of persons, and that Mr. Smith's were more than once, I believe, exhibited to numernus meetings of the Board of Agriculture, and have so ofien been shown publicly, at meetings congenial with Mr. B.'s previous pursuits in life*, at Bath, Woburn, Holknam, Goswell-street, \&c. as I have mentioned in your xxxulh vol. p. 14, and elsewhere. Let it nou be supposed, that I am herein laying any claim to a Geological Map of England of my own, since it is well known to my friends, that the obligations which I have felt myself under to Mr. Smith, as the original poatiser and promoter of useful and general investigations of the Strata, have, as much as the want of time for it, prevented my attempting any general Map, such as those of Mr. Snith and Mr. Greenough above mentioned: while at the same time, I have never been back watrl, in the very frequent interviews with which I have been honoured by the latter gentleman, to communicate or contribute any thing within my knowledge, towards the perfecting of his $\mathrm{Map}$, alwavs relying, as I do, that no publication of it will ever take place, without at the sane time, rendering auple acknowledgements to Mr. Sinith, from whose useful labours the ground work, and much of the materials in the superstructure have been obtaintel.

While I am upon the subject of Mr. Bakewell's Lectures,

* I allude here, to his investigations and work on $W$ Wol. 
or rather the account of them that you have published, permit me to mention, that I still with additional reason, as I conceive, adhere to my former position, in the Derby Report, \&c. with respect to the metalo-basaltic Limestone Rocks of Derbyshire, having louer places in the series than any other Rocks that I have sceu, or know by the Reports of others, in the British Istands; and still conclude, as I mentioned in your $102 \mathrm{~d}$ page (vol. xxxix.), that the same do not appear in the north-west of Yorkshire, in particular, as Mr. Bakewell is made to assert, p. 236; since on inquiry, I am told, that his reasons for so saying are, that "the quality of the Limestone and the Mincral Veins are the same," which 1 hold to be very inadequate marks of the identity of strata: surely Mr. B. might have done, or can now tell us, whether the succession upwards, from what he calls the 4 th Limestone, is the same, or at all allied, to that I have descrilued in Derbyshire? but above all, whether he was able to detect, all or any considerable proportion of the species of sheils and other Reliquia in the Yorkshire Limestones, that the late Mr. William Martin has figured and described in his "Petrificata Derbiensia"? Shropshire or North Wales, I have not seen, except in the distant horizon, but from what I have read of $\mathrm{Mr}$. Arthur Aikin's on those districts, and learnt from my valuable friend Mr. John Lloyd, of Wygtair, (who descended into Elden Hole, nany years ago,) and others, I conclude the limestone Rocks there, to be the same with that which underlies the great South $\mathrm{W}$ ales Cod bason, of which I have made mention in the preface to my Report, p. xiii, and which overlies a Red-Marl series, such as 1 have described at p. 270 , in your 39 th volume, but not the same probably.

That the Caverns in Limestone Rocks, were not generally formed by the washing of subierravean currents, at least, are not now enlarging or deepening by that means (as I hear that Mr. B. maintains respecting certain Caves in or near Cumberland), must be ahundanily evident, to those who will examine the bounons of such Derbyshire caverns or opens, as are counected logether, and which will be found in great part fillud up with mud, sand, shale-grit and quartz gravel, \&c., washed into them from the surface of the shale, by means af some of the Water-swallows that I have nentioned, Rep. i. p. 295 : Merlin's Cave, in the Land occupied by the late William Langsdon, Esq. (but as I am told, not belonging to him, as I have stated) and now Ee 2 
by Mr. Thomas Bird, I believe, in Eyam, is a very complete instance of this filling up of caverns by subterranean currents, instead of their being formed thereby.

Respecting the opening of the fissures occupied by $m i$. neral veins, Mr. B. (p. 3 i/) appears, like Dr. James Miller, when speaking of the Wernerian Theory (as I have observed in the note, p. 74 of my Report) to overlook the causes assigned, and principally insisted on by M. Werner himself, in his " new Theory" of Veins, lately translated, viz. slips " in rainy seasons," and the yielding and cracking of the mass by is own weight, when the rock was "at first wet and possessed little solidity," and part of it fell to the free side!. The suggestions which Mr. Bakewell offers, at the bottom of page 315 , as to the probable voltaic influence which the sides or cheeks of the Vein have had on the metallic deposits within it, is ingenious, and accords well with most of the facts which I know, particularly that remarkable one, that the bearing measures (Rep. i. 246), or particular beds of Rock between which the ore is principally lodged in the vein, were in several of the most productive Mines in Derbyshire, considerally inclined to the horizon, and are so in the Gang and some others, that are yet working: indeed, where the Limestone laps round an irregular lump of Toadstone in the floor of the Rock, as in Ashover Vellcy, Crich, Matlock High-Tor and Masson Hills, \&c., the bearing-nteasures therein, are found to conform to this shape of the floor, with very various and sometimes sudden changes in their inclination to the borizon : and furnish a gond proof, in accordance with every other ascertained fact, that these Limestone Rocks could not have been lent into their present form by injected Lara between them, as Mr. B appears, I think, disposed to concede to Mr. Whitehurst: since few persons would grant, that the crystals of spar and ore in a vein could have been soft and capable of bending, without the least fracture or distortion heing observable in them; whatever a superficial knowledge of stony depositions, might dispose them to concede, with respect to the rocks that contain the veins.

$$
\begin{aligned}
& \text { I am, sir, } \\
& \text { Yrur obcdient servant, } \\
& \text { Westminster, June 14, 1812. }
\end{aligned}
$$

